\title{
UPAYA PENINGKATAN PRESTASI BELAJAR PKN MELALUI METODE QUANTUM TEACHING DI MADRASAH IBTIDAIYAH
}

\author{
Sita Husnul Khotimah, Faiz Mubarok
}

Dosen PGMI STAI Al Hikmah Jakarta

Email: sitakh81@yahoo.com,mfaizmbr@gmail.com

Naskah diterima : 26 Agustus 2017, direvisi : 25 September 2017, disetujui : 03 Oktober 2017

\begin{abstract}
Abstrak
Rumusan masalah dalam penelitian ini adalah (1) Bagaimana penerapan Quantum Teaching pada pel ajaran PKN pada siswa kel as V MI Miftahul Falah Cipulir, (2) Bagaimana peningkatan prestasi belajar melalui metode Quantum Teaching pada pel ajaran PKN pada siswa kal as V MI Miftahul Fal ah r, (3) A pa sajakah hambatan yang dihadapi dalam penerapan Quantum Teaching pada pelajaran PKN pada siswa kelas V MI Miftahul Falah Cipulir. Penel itian ini adalah Penel itian Tindakan Kelas dengan menggunakan pendekatan penelitian kualitatif. Hasil penelitian menunjukkan bahwa berdasarkan hasil pengamatan dan wawancara maka penerapan Quantum teaching, mampu meni ngkatkan prestasi belajar siswa. Berdasarkan dari hasil observasi yang dilakukan terdapat peningkatan prestasi belajar siswa yang semula nilai rata-rata dari pretest sebesar 6,55 pada siklus I ini meningkat menjadi 7,93 atau sekitar 4\%. Sedangkan pada siklus II peningkatan prestasi belajar siswa yang semula nilai rata-rata pretest sebesar 6,55 pada siklus II ini meningkat menjadi 8,66 atau sekitar 35\%. Hal ini menunjukkann bahwa 95\% siswa berhasil meningkatkan prestasi belajar PKN dengan hasil belajar yang baik, walaupun selama penerapan masih mengalami beberapa hambatan, akan tetapi hal ini bukan berarti menafikan keberhasilan penerapan quantum teaching dalam pelajaran PKN pada siswa kelas V di MI Miftahul Falah Cipulir karena dalam penerapan quantum teaching telah menunjukkan hasilnya yaitu kegairahan dan kesenangan siswa dalam belajar, suasana yang terlihat dinamis dan siswa menjadi aktif.
\end{abstract}

Kata Kunci : Metode, Quantum Teaching, Prestasi Belajar

Pengutipan: Khotimah, Sita Husnul, \& Faiz Mubarok. (2017). Upaya Peningkatan Prestasi Belajar PKn Melalui Metode Quantum Teaching di Madrasah Ibtidaiyah. JMIE: Journal of Madrasah Ibtidaiyah Education, 1(2), 2017, 207-216. jmie.v1i2.40. 


\section{PENDAHULUAN}

Pembelajaran merupakan suatu proses yang dilakukan secara sadar pada individu atau kelompok untuk mengubah sikap dari tidak tahu menjadi tahu. Proses belajar mengajar adalah suatu kegiatan yang didalamnya terjadi proses peserta didik belajar dan guru mengajar dalam konteks interaktif, dan terjadi interaksi edukasif antara guru dan peserta didik. Akibat dari perubahan dalam diri peserta didik baik perubahan pada tingkat pengetahuan, pemahaman maupun ketrampilan (Hamalik, 2001 : 48).

Dalam kegiatan pembelajaran terdapat dua kegiatan yang sinergik, yakni guru mengajar dan peserta didik belajar. Guru mengajarkan cara peserta didik harus belajar. Sementara peserta didik belajar cara yang seharusnya mempelajari sesuatu melalui berbagai pengalaman belajar. Dengan terjadi perubahan dalam diri peserta didik berbagai aspek kognitif, psikomotorik, dan afektif. Guru yang kompeten mampu menciptakan lingkungan yang efektif dan mampu mengendalikan proses belajar mengajar, sehingga hasil bel ajar peserta didik berada pada tingkat yang optimal.

Kondisi yang mengganggu proses pembelajaran akan berpengaruh negatif terhadap hasil belajar peserta didik. Jika tidak secepatnya ditanggulangi, sangat mungkin akan menurunkan kualitas sekolah. Karena salah satu indikator keberhasilan sekolah adalah mampu mencetak lulusan yang baik. Permasalahan yang mengakibatkan penuruna pretasi belajar antara lain adalah proses pembelajaran pendidikan kewarganegaraan (PKn). Pendidikan kewarganegaraan merupakan mata pel ajaran yang secara umum bertujuan untuk mengembangkan potensi individu warga negara Indonesia, agar kiwawasan, sikap dan keterampilan kewarganegaraan yang memadai.

Pembelajaran PKn juga memungkinkan pendidik untuk berpartisipasi secara cerdas dan tanggung jawab dalam berbagai kehidupan bermasyarakat, berbangsa, dan bernegara. Pembelajaran PKn di MI Miftahul Falah Cipulir Kebayoran Lama Jakarta Selatan masih berorientasi pada transfer pengetahuan semata dengan metode ceramah yang monoton. Hal ini mengakibatkan kegagalan prestasi belajar peserta didik. Model pembelajaran yang digunakan menganut perspektif pembelajaran tradisonal yang berpusat pada guru dan menjadikan peserta didik sebagai objek pasif yang harus banyak diisi informasi. Padahal karakter peserta didik beragam yang memerlukan sentuhan khusus dari guru. Sentuhan dimaksud adalah menjadikan peserta didik aktif, inovatif, kratif, efektif terlibat dan senang selama proses pembelajaran. Dalam istilah lain disebut PAIKEM, pembelajaran yang aktif, inovatif, kreatif, efektif dan menyenangkan.

Salah satu solusi adalah penggunaan metode yang tepat, yaitu metode yang mampu membuat seluruh siswa terlibat dalam suasana pembelajaran. Oleh karena itu, peranan metode mengajar sebagai alat untuk menciptakan proses belajar mengajar (Suryasubroto, 1997 : 435).

Alternatif yang dapat dilakukan guna mengaktifkan dan meningkatkan pretasi belajar peserta didik yaitu pengguna metode Quantum Teaching. Strategi ini dapat diterapkan pada pembelajaran untuk mencapai kompentensi yang sudah ditetapkan dan diketahui peserta didik dengan membagikan bahan ajar lengkap.

Quantum Teaching berarti pegubahan bermacam-macam interaksi dalam diri peserta didik menjadi sesuatu yang bermanfaat baik bagi dirinya maupun bagi orang lain. Metode Quantum Teaching mengubah bermacam-macam interaksi yang ada dalam dan di sekitar 
momen belajar. Pelaksanaan Quantum Teaching lebih menekankan pada emosional anak, dengan prinsip 'Bawalah Dunia Mereka ke Dunia Kita dan Antarkan Dunia Kita ke Dunia Mereka "' DePorter dkk, 2000 : 7).

Berdasarkan latar belakang masalah dan pembatasan masalah, maka diperoleh rumusan masalah sebagai berikut : (1) Cara penerapan Quantum Teaching sebagai upaya peningkatan pretasi belajar pelajaran PKn di MI Miftahul Falah Cipulir Kebayoran Lama Jakarta Selatan (2) Cara peni ngkatan prestasi belajar siswa melalui metode Quantum Teaching pada pembelajaran PKn di MI Miftahul Falah Cipulir Kebayoran Lama Jakarta Selatan (3) Hambatan yang dihadapi dalam penerapan metode Quantum Teaching sebagai upaya prestasi belajar pada pembelajaran PKn di MI Miftahul Falah Cipulir Kebayoran Lama Jakarta Selatan.

Manfaat penelitian ini adalah : (1) Sebagai bahan referensi untuk mengkaji tentang penerapan Quantum Teaching (2) Pahan pertimbangan bagi guru dalam mengatasi masalah metode pembelajaran (3) Sebagai pedoman dalam peningkatan pendidikan (4) Sebagai wawasan atau gambaran cara guru mengelola kelas (5) Tambahan khazanah keilmuan bagi pembaca pada umumnya, sehingga dapat mengembangkan pengetahuan dengan wawasan yang lebih luas secara teoritis maupun praktis (6) Sebagai bahan untuk memperluas pengetahuan penulis dalam mempersiapkan diri sebagai calon tenaga pendidikan yang profesional.

\section{METODE PENELITIAN}

Penelitian ini dilaksanakan di MI Miftahul Falah Cipulir Kebayoran Lama Jakarta Selatan dengan menggunakan sampel di Kelas V. Lokasi Madrasah terletak di JL. AlMubarok II No. 6 Cipulir Kebayoran Lama Jakarta Selatan Penelitian dilaksanakan pada bulan Mei-September 2016. Pendekatan yang di gunakan dal am penelitian ini adalah pendekatan kualitatif. Pemilihan pendekatan ini karena jenis penelitianya adalah Penelitian Tindakan Kelas (PTK). Dalam PTK urutan metode adalah sama dengan urutan langkahlangkah dalam siklus penelitian, yakni: 1) perencanaan, 2) implementasi, 3) observasi, dan 4) refleksi (Wahidmurni, 2008 : 97).

Terkait dengan penelitian ini yang akan dijadikan sebagai sumber data adalah peserta didik kelas V MI Miftahul Falah Cipulir Kebayoran Lama Jakarta Selatan, pada peserta didik tersebut tidak hanya diperlukan sebagai obyek yang dikenai tindakan, tetapi juga aktif dalam kegiatan yang dilakukan. Hal ini sesuai dengan salah satu karakteristik penelitian tindakan kelas yaitu a collaborative effort and participatives (FX.Soedarsono, 2001: 2).

Dalam pelaksanaan pengumpulan data diperlukan instrumen pengumpulan data yang tepat. Posisi peneliti dalam penelitian kualitatif cukup rumit. Peneliti sekaligus sebagai perencana, pelaksana pengumpulan data, analis, penafsir data, dan akhirnya menjadi pelapor hasil penelitian (J. Moleong, 2002 : 121). Secara rinci instrumen penelitian yang digunakan dalam penelitian ini adalah:

a. Pedoman pengamatan untuk menggali data tentang suasana kelas pada saat pembelajaran sedang berlangsung, kecerian atau keatusiasan peserta didik dalam mengikuti pembelajaran, dan kejasama kelompok.

b. Pedoman wawancara untuk menggali data tentang tanggapan peserta didik terhadap penerapan metode pembelajaran yang dilaksanakan (khusus kelompok tertentu), 
untuk memperoleh informasi secara mendalam.

C. Tes digunakan untuk menggali data kuantitatif berupa hasil skor tes, skor tugas kelompok, dan skor tes kelompok (Wahidmurni, 2008 : 97).

Model dan tahapan penelitian yang digunakan oleh peneliti yaitu merujuk pada model dan tahapan penelitian tindakan kelas yang digambarkan oleh Lewin menurut Elliot gambar II (Wiriaatmadja, 2007 : 64). A dapun dal am konteks penelitian ini dijelaskan sebagai berikut:

\section{Siklus I}

a. Mengidentifikasi Masalah

Pada tahap ini penelitian berdiskusi dengan guru bidang studi terkait dengan permasalahan yang selama ini muncul dalam kegiatan belajar mengajar dikelas $\mathrm{V}$, diantaranya tetang strategi/metode apa yang digunakan dalam pembelajaran di kelas, bagai mana motivasi dan prestasi belajar peserta didik selama ini pada pembelajara PKn. Yang akan dijadikan sebagai acuan untuk perbaikan kegiatan pembelajaran berikutnya.

\section{b. Memeriksa Lapangan}

Peneliti mengobservasi permasalahan yang ada di lapangan pada saat kegiatan belajar berlangsung, untuk mengetahui permasalahan yang telah diidentifikasi sebelumnya. Kemudian penelitian juga melakukan pencatatan terhadap kejadiankejadian di lapangan. Sebagai kegiatan memeriksa lapangan penelitimel aksanakan pre test dengan menggunakan metode ceramah dan tanya jawab.

c. Perencanaan Tindakan

Setelah peneliti mengetahui pokok permasalahan yang terjadi, peneliti merencanakan tindakan dan berdiskusi dengan guru bidang studi $\mathrm{PKn}$, dengan harapan permasalahan tersebut dapat terselesaikan dan dapat meningkatkan kualitas pembel ajaran. Adapun perencanaan yang di persiapkan antara lain:

1) Membuat silabus pembelajaran

2) Membuat rencana pelaksanaan pembelajaran

3) Membuat modul pembelajaran

4) Mempersiapkan lembar observasi

\section{d. Pelaksanaan Tindakan}

Tindakan dilaksanakan dikelas $\mathrm{V}$ sesuai dengan perencanaan dalam rencana pelaksanaan pembelajaran yang telah dibuat sebelumnya. Peneliti juga menbuat catatan terhadap perkembangan yang terjadi di dalam kelas pada saat pembelajaran berlangsung. Selama pelaksanaan tindakan peneliti bertidak sebagai guru sekaligus observer yang mencatat pada lembar pengamatan observasi .

e. Observasi

Observasi dilakukan untuk mengamati pelaksanaan tindakan yang sedang dan telah dilaksanaan. Untuk melihat kesenangan dan keantusiasan peserta didik terhadap penggunaan metode Quantum Teaching dalam pembelajaran PKn. Penelitian menggunakan lembar observasi untuk mengemukakan data terkait hal-hal penting pada saat pembelajaran berlangsung. 


\section{f. Refleksi}

Refleksi dilakukan untuk melihat hasil sementara pembelajaran PKn dengan menggunakan metode Quantum Teaching.

\section{g. Revisi Perencanaan}

Hasil yang didapatkan dari siklus pertama, menjadi patokan peneliti untuk melakukan revisi perencanaan pembelajar. Revisi dilakukan oleh peneliti bersama dengan guru bidang studi untuk meninjau kembali rencana yang telah dibuat pada pertemuan sebelumnya dan mendiskusikan jika ada permasalahan baru muncul tanpa di prediksi sebelumnya.

\section{Siklus II}

\section{a. Rencana Baru}

Setelah mengetahui perkembangan permasalahan, dan setelah membuat revisi perencanaan, dalam tahap ini peneliti membuat rencana baru, untuk menanggapi masalah baru yang muncul sebagai usaha perbaikan dalam pembelajaran. Peneliti merencanakan tindakan dan berdiskusi dengan guru bidang studi, dengan harapan permasalahan dapat terselesaikan. Rencana tindakan diupayakn selalu terkait dengan tindakan yang telah dilakukan, sehingga ada rencana baru yang simultan, seperti mata rantai yang terus bersambung.

\section{b. Pelaksanaan Tindakan}

Tindakan selanjutnya adalah memperbaharui pembelajar dengan pokok bahasa selanjutnya. Dalam hal ini dilakukan dengan menerapkan rencana tindakan. Dalam hal ini peneliti juga membuat catatan terhadap berlangsungnya kegiatan belajar di dalam kelas. Rencana yang sudah matang kemudian diaplikasikan di dalam kelas sebagai bentuk tindakan. Pelaksanaan tindakan dilakukan sesuai rencana tindakan guna memperoleh hasil yang maksimal sesuai dengan yang di harapkan.

\section{Observasi}

Peneliti mel akukan pengamatan dan pencatatan dal a kegi atan pembel ajaran terkait dengan perkembangan proses belajar dengan menggunakan lembar observasi.

\section{d. Refleksi}

Peneliti mencatat hasil observasi dan berdiskusi dengan pengajar untuk mengetahui hasil tindakan yang telah diterapkan. Peneliti merefleksi hasil dan menyi mpul kan dari si kl us I sampai si kl us II sehi ngga dapt di ketahui apakah ada peni ngkatan dal am proses dan hasi 1 belajar siswa.

\section{HASIL DAN PEMBAHASAN}

\section{Perencanaan Pembelajaran}

Proses perencanaan kegiatan pembelajaran dalam menerapkan metode Quantum Teaching untuk meningkatkan prestasi bel ajar peserta didik, dilakukan sebanyak 2 si kl us selama $3 \mathrm{kal}$ i pertemuan, di lal ui dal am 4 tahap yaitu: tahap perencanaan, pelaksaan, observasi atau pengamatan dan tahap refleksi . Pada si kl us pertama, peneliti membuat perencanaan secara si stemati ka yang di sesuai kan dengan kegiatan yang akan dilakukan proses pembelajaran secara efektif dan efisien. Pada tahap ini, tidak ada masalah dalam 
perumusan perencanaan tindakan (RPP). Jadwal jam pertemuan sesuai dengan kebutuhan pelaksanaan pembelajaran. Pada siklus kedua, peneliti membuat rancangan desain pembelajaran untuk memperbai ki kekurangan-kekurangan yang ada pada si kl us pertama.

\section{Pelaksanaan Pembelajaran}

\section{Siklus I}

Pada si kl us I ini, sel ama pel aksanaan pembel ajaran di kel as dengan menggunakan Metode Quantum Teaching, terl i hat bahwasanya para peserta didik mulai antusias dan merespon positif. M ulai adanya peningkatan moti vasi belajar dibandingkan pada saat pre test. Hal ini terlihat dari aktivitas bertanya peserta di di $\mathrm{k}$ yang pada saat pre test mereka masi h mal u-mal u dan takut sal ah, pada si kl us I ini mereka sudah mulai berani bertanya meski pun bobot pertanyaannya mereka masi h bel um mencapai seperti yang di harapkan. Pada saat kegiatan bel ajar mengajar berlangsung, para peserta didik tampak gembira

dan senang, hal i ni dapat di $1 \mathrm{i}$ hat dari roman muka mereka yang tampak memancarkan semangat dan antusias untuk belajar meskipun masih ada beberapa peserta didik yang belum terbiasa dengan model pembelajaran yang diterapkan oleh peneliti.

Selama pelaksanaan pembelajaran, peneliti bertindak sebagai guru sekaligus sebagai observer yang mencatat lembar pengamatan pada pedoman observasi. Hasil pengamatan pada tahap pendahuluan, terdapat peningkatan motivasi, hal ini dikarenakan peserta didik merasa mendapatkan penyegaran dalam kegiatan belajar mengajar, sehingga mereka berusaha memusatkan perhatian selama pembelajaran berlangsung. Akan tetapi, memasuki kegiatan penjelasan materi secara global, aktivitas peserta didik dalam mengajukan pertanyaan masih kurang. Hal ini dikarenakan peserta didik masih belum terbiasa untuk mengajukan pertanyaan. Sebaliknya, mereka lebih suka menjawab pertanyaan.

Memasuki tahap kegiatan inti, peneliti membagi murid menjadi enam kelompok, masing-masing kelompok terdiri atas lima (5) orang anggota kelompok (tiap kelompok memiliki anggota yang heterogen, baik jenis kelamin maupun kemampuannya). Kemudian peneliti memberi tugas kepada masing-masing kelompok untuk saling membantu dalam menguasai bahan ajar, yaitu membuat gambar peta dunia. Dalam pembelajaran ini, peneliti melatih peserta di di k untuk bekerjasama dengan teman dal am kel ompok.

Berdasarkan hasil pengamatan, diketahui bahwa prestasi belajar siswa masih belum seperti yang diharapkan atau bisa dikatakan masih rendah. Ini dapat dilihat dari lembar observasi peserta didik yang menunjukkan bahwa aktivitas kerjasama peserta didik belum mencapai apa yang diharapkan. Kegiatan kelompok ini masih didominasi oleh para peserta didik yang aktif, sedangkan mereka yang pasi f cenderung mengi kuti hasi 1 yang tel ah di kerjakan kelompok. Hal ini dikarenakan adanya perbedaan individual pada masingmasing peserta didik. Mereka yang aktif adalah mayoritas yang memiliki prestasi di kelas, dan mereka yang pasif adalah yang berprestasi kurang atau sedang dan mereka cenderung kurang percaya di ri pada kemampuannya. 
Indi kator peningkatan prestasi belajar peserta didik tercermi n dalam semangat, antusi as dan rasa i ngi n tahu peserta di di k dal am K B M. Sedangkan i ndi kator peningkatan prestasi belajar peserta didik terl i hat dari hasil belajar siswa. Berdasarkan hasil observasi yang telah dilaksanakan terdapat sedikit peningkatan prestasi belajar peserta didik yang semula nilai rata-rata kelas dari pre test sebesar 6,55 meni ngkat menjadi 7,93 atau seki tar $4 \%$.

\section{Siklus II}

Pada si kl us II i ni, hasi l pengamatan menunj ukkan bahwa peserta di di k mengalami peningkatan motivasi belajar yang cukup menggembirakan dalam mengi kuti kegi atan bel aj ar mengajar, peserta di di k sudah terbi asa bertanya dan mengemukakan pendapat apabi $l$ a penel $i$ ti memberi kan permasal ahan. Dan ti dak hanya motivasi belajar peserta didik yang mengalami peningkatan, akan tetapi prestasi atau hasil belajar mereka juga mengalami peningkatan yang begitu menggembi rakan. Pada tahap pendahul uan, kegi atan peserta di di k cukup bagus. Hal i ni dapat di 1 i hat dari:

a. Peserta didik sangat antusias mengikuti kegiatan belajar mengajar.

b. Pada saat penjelasan materi secara global peserta didik juga berani mengajukan pertanyaan dan pendapat.

Memasuki kegi atan i nti, keti ka guru membentuk kel ompok, masi ngmasi ng kel ompok di beri materi untuk di pel ajari dan di kuasai . K eti ka penel i ti memberi tugas/pembagi an materi pada masi ng-masi ng kel ompok, peserta di di k meneri ma tugas dengan enak hati dan atas anjuran penel iti mereka berusaha untuk sal i ng membantu memahami materi yang di bebankan pada masi ngmasi ng kel ompok. $\mathrm{K}$ emudi an peserta didik mengi 1 ustrasi kan materi dengan kehidupan sehari-hari. $\mathrm{M}$ ereka tampak bersemangat dalam mengerjakan tugas, mereka sal i ng membantu memahami materi yang di beri kan. M ereka sal i ng mel ontarkan pertanyaan demi tercapai nya hasi 1 bel ajar yang memuasakan serta terus berdiskusi dalam waktu yang ditentukan, serta menampakkan rasa gembi ra dan senang sel ama mengi kuti pembel ajaran. Ti dak tampak rasa 1 eti h dari roman muka mereka, bahkan ketika peneliti memberi kesempatan untuk mengajukan pertanyaan, dengan serentak para peserta didik berebut bertanya kepada guru.

Penel iti menangkap komuni kasi dan kerjasama yang sudah sangat bai k bahkan dapat di katakan begitu di nami s dan sempurna pada di skusi antar sesama anggota kel ompok, karena masi ng-masi ng peserta di di k merasa ti dak ada beban rasa mal u dan takut sal ah dal am mengaj ukan pendapat. Sel ai n i tu hampi r 95\% dari mereka sudah sangat terbiasa dan menyatu dengan model pembelajaran yang peneliti terapkan di kelas $\mathrm{V}$ ini, bahkan mereka mengharapkan agar metode ini dapat diterapkan pada semua mata pelajaran.

Indikator peningkatan motivasi belajar peserta didik tercermin dalam bertambahnya semangat, antusi as dan rasa i ngi n tahu peserta di di k dal am K B M. Sedangkan i ndi kator peni ngkatan prestasi belajar peserta di di $\mathrm{k}$ terl $\mathrm{i}$ hat dari meni ngkatnya hasi 1 bel ajar peserta di di k.

Berdasarkan hasi 1 observasi yang tel ah di 1 aksanakan terdapat peni ngkatan prestasi bel ajar peserta di di $\mathrm{k}$ terl $\mathrm{i}$ hat dari ni 1 ai rata-rata kel as yang semul a ni 1 ai rata-rata kel as dari pre test sebesar 6,55 meni ngkat menjadi 8,66 atau sekitar 35 
$\%$. Sedangkan peni ngkatan prestasi belajar antara si kl us II dengan si kl us I adal ah pada si kl us I ni 1 ai rata-rata kel as sebesar 6,55 meni ngkat menjadi 8,66 atau sekitar $30 \%$.

Untuk lebih mendapatkan gambaran kuali tati $\mathrm{f}$ secara mendalam terhadap penerapan metode Quantum Teaching, penel iti melakukan wawancara yang di tetapkan sebagai i nforman.

$\mathrm{H}$ asi 1 wawancara adal ah sebagai beri kut, terhadap pertanyaan "Bagaimanakah tanggapan kamu terhadap penerapan metode pembelajaran tadi"? seorang peserta di di $\mathrm{k}$ yang termasuk memi 1 i ki kemampuan diatas rata-rata mengatakan.

"Say a suka deng an cara m eng ajar bapak karena bikin say a gak mal u.

Sebelumnya gak pernah disuruh maju kedepan kel as untuk mempresentasikan hasil di skusi, jadi aku masi h agak mal u, tapi karena suasananya ramai dan menyenangkan jadi saya gak takut lag i kalo m aju.( Hasil Wawancara Kelas V aang kemampuan diatas rata-rata (5 Oktober 2016)"

Sedangkan peserta di di k yang termasuk si swa yang memi l i ki kemampuan di bawah rata-rata mengatakan.

"Enak banget pak belajar PKn, saya seneng banget kalo di ajar pa Faiz, apalagi saya dikasik permen sam a pak Faiz. A ku jadi tam bah seneng, hehehe pokoknya aku seneng banget $\mathrm{Pa}$...." ${ }^{\prime 10}$ [ID

Dengan demikian tanggapan para infrm an adalah positif terhadap pelaksanaan pembelajaran dengan menggunakan metode quantum teaching karena kedua peserta didik menyatakan senang terhadap m etode pembelajaran yang mereka alam i. Dengan demikian, metode pem belajaran yang diterapkan sangat memberikan manfaat kepada para peserta didik, mereka merasakan suasana yang akrab dengan teman-tem annya, lebih rileks, mendapat pengalaman baru dan men gerjakan tugas dengan baik dan benar sesuai dengan kelompok masing-masing.

\section{Hambatan Yang Di Hadapi}

Sebagainama yang telah peneliti paparkan selama pemberian tindakan pada siklus pertama, dan kedua bahwasannya didapatkan kendala-kendala dalam pelaksanaan metode Quantum Teaching. Diantaranya yaitu, peserta didik belum terbiasa terhadap pembelajaran yang $\mathrm{m}$ enerapkan metode Quantum Teaching sehingga mereka masih banyak yang mengalami kebingungan, kemudian pelaksanaan Metode Quantum Teaching membutuhkan waktu yang banyak sedangkan guru harus menyesuaikan waktu sesuai dengan waktu yang dialokasikan.

Dari

hasil pelaksanaan tindakan siklus I dan II setelah peneliti melakukan

pengamatan dapat diketahui adanya hambatan pada saat penerapan Quantum Teaching pada pelajaran PKn yaitu:

a Terbatasnya

pengetahuan dan penguasaan yang dimiliki oleh para guru tentang

Quantum Teaching sebagai metode yang masih baru.

b. Terbatasnya sarana dan fasilitas pendidikan.

- Terbatasnya waktu yang dialokasikan. 


\section{KESIMPULAN}

1. Penerapan Quantum Teaching pada pembelajaran PKn untuk meni ngkatkan prestasi belajar siswa pada kelas V MI M iftahul Falah Cipulir Kebayoran Lama Jakarta Sel atan sesuai dengan rencana yang tel ah di susun. Pada si kl us I penel i ti berhasi 1 menjel askan pada peserta didik tentang memahami penti ngnya keutuhan negara kesatuan republ i k i ndonesi a (N K RI). Penel i ti $\mathrm{j}$ uga menjel askan kompetensi dasar yang harus dikuasai, melakukan KBM sesuai RPP, kemudian peneliti melakukan post tes untuk mengeval uasi pemahaman peserta didi k. Pada si kl us ke II peneliti melakukan wawancara terhadap guru-guru dan mengadakan post tes.

2. Berdasarkan hasil penelitian yang telah dilakukan menunjukkan bahwa pembelajaran dengan menggunakan metode Quantum Teaching dapat meningkatkan prestasi belajar peserta didik kelas V MI M iftahul Falah C i pul i r Kebayoran Lama Jakarta Selatan terhadap materi PKn. Hal ini dapat ditunjukkan dari hasi 1 eval uasi yang tel ah di 1 aksanakan terdapat peni ngkatan prestasi belajar peserta didi k yang semul a ni 1 ai rata-rata dari pre test sebesar 6,55 pada si kl us I i ni meni ngkat menjadi 7,93 atau sekitar 4\%. Sedangkan pada si kl us II peni ngkatan prestasi belajar peserta didik yang semula nilai rata-rata pre test sebesar 6,55 pada si kl us II ini meni ngkat menjadi 8,66 atau sekitar 35\%. Ini menunj ukkan 90\% peserta didik berhasil dal am belajar PKn dengan menggunakan metode Quantum Teaching.

3. Pemberian ti ndakan pada si $\mathrm{kl}$ us pertama dan kedua bahwasannya didapatkan kendal a-kendal a dal am pel aksanaan Quantum Teaching antara lain peserta didik belum terbiasa terhadap pembelajaran dengan menggunakan metode Quantum Teacbing sehi ngga mereka masi h banyak yang mengal ami kebi ngungan, kemudi an pelaksanaan Quantum Teaching membutuhkan waktu yang banyak sedangkan guru harus menyesuai kan dengan waktu yang di al okasi kan. Sel ai n $i$ tu j uga terbatasnya sarana dan fasi 1 i tas yang di mi li ki ol eh sekol ah.

\section{DAFTAR PUSTAKA}

A rief S. Sadi rma dkk. 2009. Media Pendidikan. Jakarta: Rajawal i.

Azhar Arsyad. 1997. Media Pengajaran. Jakarta: Raja Grafindo Persada.

Bobby DePorter, Mark Reardon, Sarah Singer, Nourie. 2000. Quantum Teaching mempraktekkan Quantum learning di Ruang-ruang Kelas, Bandung: Kaifa.

Braner 1962. Metode Penelitian Pendidikan Kuantitatif, Kualitatif. Bandung

Departemen Pendidikan Nasional. 2008. Kamus Besar Bahasa Indonesia. Jakarta: Balai Pustaka

FX Sudarsono. 2001. Aplikasi Penelitian Tindakan Kelas Jakarta: Departemen Pendidikan NasionaL.

Hasil wawancara kepala sekolah Rukiah S.Pd.I MI M iftahul Falah Cipulir (5 Oktober 2016)

$\mathrm{H}$ asi 1 wawancara kel as $\mathrm{V}$ aang kemampuan di atas rata-rata (5 O ktober 2016)

$\mathrm{H}$ asi 1 wawancara wal $\mathrm{i}$ kel as V A an Rohyan S.Pd.I MI M i ftahul Fal ah C i pul i 


$$
\text { r ( } 5 \text { O ktober 2016) }
$$

$\mathrm{H}$ asi 1 wawancara kel as V kemampuan di bawah rata-rata ( 5 O ktober 2016)

H ery N oer A 1 y. 1999. Ilmu Pendidikan Islam. Jakarta: Logos.

Iskandar. 2009. Psikologi Pendidikan. Jakarta: Gaung Persada

Ivor K.Davi es. 2008. Pengelolaan Belajar. Jakarta:CV.Rajawal i.

Lexy. J.. M oleong. 2002. Metodologi Penelitian Kualitatif. Bandung: PT Remaja Rosdakarya.

Nana Syaodi h Sukmadi nata. 2009. Landasan Psikologi Proses Pendidikan. Bandung: PT.Remaja Rosdakarya.

Oemar H amal i k. 2001. Proses Belajar Mengajar. Bandung: B umi A ksara.

Ramayul is, 2008. Ilmu Pendidikan Islam. Jakarta: K al am M ul i a

Rochiati Wi riaatmadja.2007. Metode Penelitian Tindakan Kelas. Jakarta: PT. Ri naka $\mathrm{C}$ i pta.

Saiful Bahri Jamarah. 2010. Guru dan Anak Didik dalam Interaksi Edukatif. Jakarta:Rineke

Soedarsono, FX. 2001. Aplikasi Penelitian Tindakan Kelas. Jakarta: PAN-PPAI Universitas Terbuka.

Wahidmurni, Nur Ali. 2008. Penelitian Tindakan Kelas (Pendidikan Agama Dan Umum Dari Teori Menuju Praktek Disertai Contoh Hasil Penelitian). Malang: UM Press.

Wina Sanjaya. 2008. Strategi Pembelajaran. Jakarta : Prenada Media.

Winarno Surakhmat. 1987. Pengantar Penelitian Ilmiah, Dasar dan Metoda Teknik. Bandung: CV. 